\title{
Perceived Challenges of Implementing An Integrated Talent Management Strategy at A Tertiary Institution in South Africa
}

\author{
Owen Zivanai Mukwawaya ${ }^{1}$, Cecile Gerwel Proches ${ }^{2} \&$ Paul Green $^{3}$ \\ ${ }^{1}$ Department of Psychology, Sefako Makgatho Health Sciences University, Pretoria, South Africa \\ ${ }^{2}$ Graduate School of Business and Leadership, University of KwaZulu-Natal, Durban, South Africa \\ ${ }^{3}$ Faculty of Business and Management Sciences, Cape Peninsula University of Technology, Cape Town, South \\ Africa \\ Correspondence: Cecile Gerwel Proches, Graduate School of Business and Leadership, University of KwaZulu-Natal, \\ Durban, South Africa.
}

Received: June 8, 2021

Accepted: July 31, 2021

Online Published: August 6, 2021

doi:10.5430/ijhe.v11n1p100

URL: https://doi.org/10.5430/ijhe.v11n1p100

\begin{abstract}
The aim of this study was to investigate and delineate the perceived challenges of implementing an integrated talent management strategy at a South African tertiary institution. The study was conducted at a relatively new university that opened its doors on the $1^{\text {st }}$ of January 2015 . Since the inception of the university under study, the institution has grown considerably but without proper policies and strategies in place to ensure its competitiveness and sustainability within the current Higher Education and Training sector in the country. A qualitative research methodology in the form of semi-structured interviews conducted with a convenience sample of 10 participants was employed to execute the study. The sample was drawn from the population of directors and official representatives of administrative, academic and support staff. The inclusion of these participants was premised on the idea that by virtue of their job description, they would be most exposed to talent management issues. Results of the study indicate that the major challenges experienced in implementing an integrated talent management strategy at the university include lack of management commitment and budget, as well as unionism and resistance to change amongst staff. As such, the primary recommendations of this study are for demonstrated commitment by university management towards accessing adequate finances to facilitate the implementation of a sound talent management strategy that will assist in promoting both the quality and longevity of the tertiary education institution in question.
\end{abstract}

Keywords: talent management, universities, higher education, South Africa, challenges, management, integrated talent management strategy

\section{Introduction}

Talent management as a concept, lacks a clear definition. Many scholars differ in defining the concept, hence there is no single universally accepted definition for it as such (Thunnissen, Boselie \& Fruytier, 2013). Erasmus, Loedolff, Mda and Nel (2013) define talent management as the process of establishing a continuous supply of highly productive individuals in the right job at the right time. Their definition also includes the implementation of strategies designed to increase workplace productivity, as well as to improve processes for attraction, development, retention, and efficient utilization of people with the required skills and competencies to meet both current and future strategic business needs.

Talent management is also described as a practice that is focused on enticing scarce resources in a competitive labour market (Yarnall, 2011). Barkhuizen, Mogwere and Schutte (2014) echo Erasmus et al. (2013) and maintain that the talent management process involves developing, retaining and engaging workers in the organisation. Festing, Kornau and Schafer (2015) further expound talent management as the practice of managing people and ensuring that both workers and the organisation achieve set objectives. Although talent management as a concept thus has a number of varied definitions, there appears to be a general consensus amongst scholars that talent management as a practice involves the attraction, identification, recruitment and retention of skilled employees who are able to create value within an organisation.

Inherent within both the concept and practice of talent management is the assumption that there exists suitable talent to manage. In other words, talent cannot be managed unless there are skilled and experienced staff to manage. 
Similarly, talented staff cannot be managed by senior staff who are not themselves skilled and experienced. Shikweni, Schurink and Van Wyk (2019) state that South Africa is ranked poorly with regards to people's development and labour market efficiency. Furthermore, evidence from research shows that there is a growing concern in relation to the sustained supply of qualified and experienced tertiary education staff in particular, as many senior academics who fall within the generation commonly referred to as 'baby boomers' are now reaching retirement age and leaving the workforce. This is resulting in creating vacancies that may be difficult to fill (HESA, 2011; Musakuro, 2018).

The sustainability of any organisation is directly dependent on the quality of its primary resource, namely the employees who make up that organisation. A tertiary education institution's survival thus depends on developing the quality of its academic faculty staff, without which there will be both financial and educational consequences (Barkhuizen et al., 2014; Musakuro, 2018). By inference, these consequences may in turn impact upon the education of a nation's human resources that would likely have consequences for that country's economy as a whole. It is therefore important to acknowledge that a nation's competitiveness and development of the knowledge of the population largely depends on its population obtaining solid and sustainable tertiary education.

Koketso and Rust (2012) note that some organisations in South Africa are operating without an effective talent management strategy in place. This strategy should ideally involve the need to drive the strategic goals of the organisation forward, deliver on assigned mandates and ensure sustainability in the long run. The university identified for this study continues to lose talented employees periodically (Personal Communication with Human Resources Director, 2017). Challenges with staff turnover, poor working conditions, uncompetitive compensation and employee frustration continue to plague this tertiary education institution and many others (Koketso \& Rust, 2012; Musakuro, 2018). In addition, evidence from this study indicates that this university spends large sums of money on the talent attraction process for replacing the personnel who leave the university. As such, it was deemed imperative to conduct this research within this particular university with the objective of identifying and dissecting their talent management procedures in order to provide recommendations for the sustainability of a competitive South African tertiary education institution.

As outlined in the introduction to this article, in today's fiercely competitive global economy, no organisation can survive without effective talent management. As such, many organisations, including universities, are making concerted efforts to build, develop and retain their human capital through effective talent management strategies. The current study focused on a relatively new university that seems to lack effective strategies to both mobilise and retain the necessary talent for sustainable growth and survival of the institution within the competitive global higher education landscape. The emphasis on higher education rankings is forcing universities to make earnest efforts towards building and developing a formidable workforce. This is in light of the realisation that it is an organisation's talent that distinguishes it from another with regards to the putative competitive race (Makondo, 2014). Issues of employee turnover, poor compensation and undesirable working conditions have been identified as the major challenges frustrating the talent management efforts of many tertiary education institutions including the institution under study (Samuel \& Chipunza, 2013). In light of the above, this study focused on determining the perceived challenges of implementing an effective talent management strategy at a local university.

The study was guided by the following objectives:

- To determine the perceived challenges of implementing a talent management strategy at this university

- To identify the factors that make the implementation of a successful talent management strategy difficult within this university environment.

\section{Literature Review}

\subsection{An Overview of Talent Management in Higher Education Institutions}

Literature shows that talent management is relatively new in universities despite its relevance for these institutions in offering a practical way of achieving a competitive edge. In a research study conducted by Rudhumbu and Maphosa (2015) in Botswana, it was found that talent management practices utilised in tertiary education institutions in this country are still lagging behind because the knowledge and capability to apply these talent management strategies is lacking (Festing \& Schafer, 2014; Rudhumbu \& Maphosa, 2015; Simataa \& Pearse, 2018).

In light of the above observation, this research seeks to provide knowledge and capability in the application of talent management strategies. Proper implementation of talent management strategies in tertiary institutions will ensure that these institutions enjoy a competitive advantage over other institutions. The effective application of talent management strategies at tertiary institutions will also ensure that these institutions cut costs of replacing employees who have left (Koketso \& Rust, 2012; Mabaso \& Dlamini, 2018; Musakuro, 2018). 
Koketso and Rust (2012) posit that efficient talent management practices result in dedicated workers and thereby a substantial reduction in labour turnover, an increase in employee engagement and productivity, and talent retention. Many authors also note that most workers who show dedication perform better and are less likely to quit (Erasmus et al., 2013; Koketso \& Rust, 2012; Mabaso \& Dlamini, 2018; Shikweni, Schurink \& van Wyk, 2019).

\subsection{Talent Management in Higher Education Institutions in South Africa}

Theron, Barkhuizen and du Plessis (2014) argue that there is a dire need to exponentially grow the number of university employees both globally and in South Africa. The major problems associated with universities' failure to implement effective talent management strategies include inter alia, brain drain, a gender gap, unattractive salary offers, and lack of adequate training, among others (Onah \& Anikwe, 2016; Mabaso \& Dlamini, 2018).

Makondo (2014) reported that in the South African higher education context, the problem of academics leaving their employers is endemic because data indicates that a substantial number of academics leave many higher education institutions to join organisations that offer far better conditions of service, hence causing a shortage of knowledge workers (Selesho \& Naile, 2014).

Literature posits that the generation of 'baby boomers' in organisations such as universities are soon to retire and as such these institutions will lose valuable skills, experience and knowledge when these vital employees exit the university. In addition, younger university employees may resign for the various reasons that have already been mentioned, thereby forcing many tertiary educations into a corner where they will be put under the spotlight. This will result in universities having to rely on Generation X or Y employees in their search for talent (Van Zyl, Mathafena \& Ras, 2017).

The discussion below will focus on the conceptual framework underpinning this study, which is informed by various beliefs regarding talent management that are evident in the literature on the subject.

\subsection{Conceptual Framework}

There are various perspectives and approaches related to talent management. Meyers and Van Woerkom (2014) proffer a clear delineation of talent in their famous inclusivity and exclusivity approaches. The exclusive approach believes that "talent" denotes a smaller percentage of workers who are high achievers, have high potential and are critical in driving the strategic objectives of the organisation. The inclusive approach on the other hand regards "talent" as all employees of an organisation (Capelli \& Keller, 2014). The major question that relates to "talent" is whether or not it is an innate (stable) or acquired aspect.

In this study, the inclusive/stable talent management philosophy was adopted since the researcher was of the opinion that all employees in an organisation have the ability to contribute meaningfully to the organisation, hence the desire to develop an integrated talent management strategy (Meyers, Van Woerkom \& Dries, 2013). The other motive for the choice of the inclusive/stable approach is that most studies on talent management in tertiary education institutions focus on elite groups and academics whilst giving less attention to other employees (Erasmus et al., 2013; Meyers et al., 2013).

\section{Materials and Methods}

Ponterotto (2005) defines a research paradigm as a set of interrelated assumptions about the social world that provide a philosophical and conceptual framework with the aim of studying the world. Blanche et al. (2006:6) states that "paradigms are all-encompassing systems of interrelated practice and thinking that define for researchers the nature of their enquiry along three dimensions: ontology, epistemology and methodology". In this study, the researcher adopted interpretivism as a research paradigm. Blanche et al. (2006) posit that the goal of an interpretive approach to research is to explain the subjective reasons and meanings that lie behind social action.

The study was aimed at investigating the perceived challenges experienced when implementing an integrated talent management strategy in a tertiary institution in Pretoria, South Africa. This study therefore employed a qualitative research methodology. The research approach chosen involved the gathering of data through conducting semi-structured interviews to investigate individual experiences, opinions, feelings and perceptions (Leedy \& Ormrod, 2014).

Before the collection of data, the tertiary institution's management was contacted and informed about the purpose of the study. The tertiary institution was purposefully contacted to seek permission to undertake this study. Owing to the likely benefits that could accrue from the research results, permission to conduct the study was promptly granted by the tertiary institution in question. 
A total of 10 semi-structured interviews were conducted face to face with the research participants. The participants were drawn from the management of the university within various departments. Among the participants were also representatives from the academic, support and administrative permanent staff of the university. This allowed for diverse opinions and perspectives to be gathered on the topic. The semi-structured interviews were conducted in different agreed upon settings that were convenient to the participants.

The sample of participants who shared their experiences regarding the perceived challenges of implementing an integrated talent management strategy at a tertiary institution in South Africa were interviewed in the English language. English was selected because all the participants were comfortable in providing responses in this language.

The duration of each interview session was approximately 45 minutes but sometimes took up to an hour for those respondents who had a lot to discuss. A digital recorder was used to record all the semi-structured interviews undertaken. Considering the fact that the study was qualitative, the interview questions focused on perceptions, opinions, ideas and feelings of the participants in respect to the research questions.

An overview of the demographic details of the participants in the semi-structured interviews is presented in Table 1 below.

Table 1. Demographic Details of Participants for Semi-structured Interviews

\begin{tabular}{|c|c|c|}
\hline Key Characteristic & Category & Number \\
\hline \multirow[t]{4}{*}{ Rank } & Director & 7 \\
\hline & Lecturer & 1 \\
\hline & Administrator & 1 \\
\hline & General Worker & 1 \\
\hline \multirow[t]{2}{*}{ Gender } & Male & 7 \\
\hline & Female & 3 \\
\hline \multirow[t]{3}{*}{ Race } & African & 5 \\
\hline & White & 4 \\
\hline & Indian & 1 \\
\hline \multirow[t]{4}{*}{ Work Experience } & Less than 2 years & 1 \\
\hline & $3-5$ years & 1 \\
\hline & $6-10$ years & 3 \\
\hline & $11-15$ years & 5 \\
\hline
\end{tabular}

Collected data from the semi-structured interviews was analysed by NVIVO software version 11. Content analysis is a method of identifying, analysing, and reporting patterns within collected data. It minimally organises and describes data set in rich detail (Braun \& Clarke, 2013). Content analysis was deemed suitable for the particular study because it addresses questions related to people's experiences, views and perceptions. Various themes emerged and were categorised by the researcher in terms of the main contributing factors that could account for the perceived challenges experienced by affected individuals regarding the implementation of an integrated talent management strategy in a tertiary education institution in South Africa.

\section{Results and Discussio}

This research reported a myriad of perceived challenges in the implementation of an integrated talent management strategy at a tertiary education institution in South Africa. Participants highlighted various perceived challenges in implementing an integrated talent management strategy at the tertiary institution under study however as stated above, during content analysis three overarching themes arose. These included the lack of management commitment, lack of budget and an over dependence on unionism displayed by staff as resistance to certain positive initiatives that have been taken by top management of the institution. 


\subsection{Lack of Management Commitment}

The secondary research undertaken prior to conducting this study indicates that one of the greatest challenges that can be anticipated when implementing an integrated talent management strategy at a university is lack of management commitment. It is therefore reasonable to argue that a good plan can be put on paper but its implementation may not be as well executed. Most of the research participants highlighted that university management frequently made promises yet failed to follow through on these promises.

In the words of one of the participants, "the other challenge that I have seen in implementing a talent management strategy is lack of management commitment. Yes, you can come up with a very good idea but top management might not commit to what is on paper". (P3)

The above statement appears to be contrary to some of the key findings of Van Zyl et al. (2017), who claim that communication has been reported as one of the challenges experienced in implementing an integrated talent management initiative. In a study conducted by Koketso and Rust (2012), it was reported that communication in the form of providing employees with regular feedback about their performance has been identified as one of the greatest challenges that affects the proper implementation of talent management in the City of Cape Town (Koketso \& Rust, 2012). It was further reported that some employees go beyond the call of duty and even risk their lives for the sake of the organisation but management do not seem to recognise these employees' efforts by giving them regular feedback.

The literature reviewed is generally of the view that senior management commitment is a key ingredient in the recipe for talent management practices to excel in organisations. Previous studies further show that management's mindset towards talent management is a significant predictor of turnover intentions for younger generations in the workplace (Theron et al., 2014). Literature also shows that management's commitment to talent management also play a vital role in enhancing positive work related behaviours such as job satisfaction, organisational satisfaction and organisational commitment.

\subsection{Lack of Budget}

The research for this study indicated that lack of budget is a challenge that appears to thwart any efforts made by university management to establish robust talent management initiatives and strategies. It is common knowledge that issues related to retaining key talent within the organisational context requires the organisation to have an adequate budget that ensures that this initiative is well supported.

Some participants stated that one of the greatest challenges that can be experienced in implementing an integrated talent management strategy at the university is budgetary constraints.

In the words of one of these participants, "It is always difficult to implement something when there is lack of budget so one of the challenges that might derail the implementation of an integrated talent management strategy at this university you know because of the fees must fall issue, we need funding from Government." (P3)

In support of the idea highlighted above, another participant stated that "in the first instance, I think it will be financial resources. We all know that the students had issues with high fees and not paying fees at all. So I think as a result of that, the financial pressure on the university is quite a lot. So the finance is a problem because good people come at a price". (P8)

The above finding differs from certain findings reported in literature (Koketso \& Rust, 2012). In a study conducted by Koketso and Rust (2012) on perceived challenges of talent management in the city of Cape Town, it was reported that lack of performance incentives is one of the greatest challenges that undermine all efforts to implement talent management initiatives. It was further reported that although the City awards annual performance bonuses, most of the participants felt that the City could come up with additional ways for rewarding top talent. Most of these participants suggested that the City should try merit allowances and show recognition by issuing certificates for employees who go the extra mile regarding their work. This is indicative of most people's need for visible acknowledgment that their contribution matters. Regular feedback from management therefore appears to be even more vital than monetary rewards when it comes to fostering a culture of high performance within an organisation.

\subsection{Unionism and Resistance to Change}

Unionism and resistance to change have also been highlighted as one of the challenges experienced in implementing an integrated talent management strategy at the university. It was noticed during data collection that the work environment at the university is highly unionised. This seems to make employees very rigid with regards to allowing change to take place especially if the change is deemed not to be in line with the beliefs of the union. 
In support of the above observation, one of the participants stated that, "I don't think people are willing to change and also the issue of unionism...". (P4)

This particular finding is very similar to that of Koketso and Rust (2012) whose study reported that unions and management are often seen to be at loggerheads in relation to issues of talent management. Van Zyl et al. (2017) maintain that unions and management normally do not agree on succession planning especially with regards to employee promotion. Literature also posits that the bureaucratic nature of the public service sector poses a significant challenge for talent management implementation within this sector (Van Zyl et al., 2017).

Koketso and Rust's study (2012) also evidenced that it is difficult to implement talent management initiatives when the workforce is aging and as such, issues like succession planning will have an impact on management. Van Zyl et al. (2017) highlight that even young employees are affected because although they arrive with all the energy and new ideas necessary for an organisation to be able to evolve and adapt to change, most of these ideas will eventually be lost if they are not recognised by management.

\section{Conclusion}

This study was aimed at investigating the perceived challenges of implementing an integrated talent management strategy in a South African university. Qualitative research in the form of semi-structured interviews with a convenience sample of key staff elucidated that the major challenges currently facing the university under study are lack of management commitment, lack of budget, unionism and resistance to change.

The findings of this study indicate the primary recommendation that university management needs to develop better strategies and display greater commitment towards overcoming the financial challenges and staff's resistance to change in an effort to implement an integrated talent management strategy that will ensure the long-term sustainability of the institution within the competitive context of higher education, both in South Africa and globally. The findings also indicate that in order to achieve this primary recommendation, access to adequate financial assistance is imperative. Further recommendations based on the findings of this study include:

- A visible effort from leadership in higher education institutions to familiarise themselves with the subject of talent management, possibly by engaging experts in the field to assist with both education and implementation of effective strategies.

- Leadership to engage with staff in order to properly understand and address the challenges they experience in the workplace that are hindering talent development.

- Leadership in tertiary education institutions should be held fully accountable for all talent management problems and the addressment thereof and as such should also be held accountable for the quality and sustainability of their institutions.

The present study has implications for future talent management studies in other South African as well as international higher education institutions. As an example, further research could focus on the impact of talent management challenges on the quality of teaching and learning within universities. A study that reviews talent management strategies within privately funded versus state funded higher education institutions may also be a worthy contribution towards expanding the existing body of knowledge on this subject.

Despite a considerable amount of effort taken to ensure that this research is without flaws, it must be acknowledged that this study is not immune to limitations. The study only focused on perceptions of a few key stakeholders in one public university. The convenience sample of 10 participants makes it difficult to generalise the research findings to other contexts. Secondly, a complementary quantitative study across a wider population may assist in determining the extent of the challenges identified in the qualitative study and gain more insight into how these challenges could be overcome. Future studies can also explore the attitudes of staff (academic and support) in other higher education institutions in South Africa.

\section{References}

Barkhuizen, N., Mogwere, P., \& Schutte, N. (2014). Talent management, work engagement and service quality orientation of support staff in a higher education institution. Mediterranean Journal of Social Sciences, 5(4), 69-77. https://doi.org/10.5901/mjss.2014.v5n4p69

Blanche, M. T., Blanche, M. J. J., Durrheim, K., \& Painter, D. (2006). (Eds.). Research in practice: Applied methods for the social sciences. Cape Town: University of Cape Town Press.

Braun, V., \& Clarke, V. (2013). Successful qualitative research: A practical guide for beginners. London: Sage. 
Capelli, P., \& Keller, J. R. (2014). Talent management: Conceptual approaches and practical challenges. Annual Review of Organizational Psychology and Organisational Behavior, 1(6), 305-331. https://doi.org/10.1146/annurev-orgpsych-031413-091314

Erasmus, B., Loedolff, P., Mda, T., \& Nel, P. (2013). Managing training and development in South Africa (6 ${ }^{\text {th }}$ ed.). South Africa: Oxford University Press.

Festing, M., Kornau, A., \& Schäfer, L. (2015). Think talent-think male? A comparative case study analysis of gender inclusion in talent management practices in the German media industry. The International Journal of Human Resource Management, 26(6), 707-732. https://doi.org/10.1080/09585192.2014.934895

Festing, M., \& Schäfer, L. (2014). Generational challenges to talent management: A framework for talent retention based on the psychological-contract perspective. Journal of World Business, 49(2), 262-271. https://doi.org/10.1016/j.jwb.2013.11.010

HESA (2011). A generation of growth: Proposal for a national programme to develop the next generation of academics for South African higher atucation. Available https://www.usaf.ac.za/wp-content/uploads/2017/03/12430-HESA-Next-Generation-V4.pdf

Koketso, L. P., \& Rust, A. A. (2012). Perceived challenges to talent management in the South African public service: An exploratory study of the City of Cape Town municipality. African Journal of Business Management, 6(6), 2221-2233. https://doi.org/10.5897/AJBM11.2169

Leedy, P. D., \& Ormrod, J. E. (2014). Practical research: planning and design (10 ${ }^{\text {th }}$ ed.). USA: Pearson.

Mabaso, C. M., \& Dlamini, B. I. (2018). Total rewards and its effects on organisational commitment in higher education institutions. SA Journal of Human Resource Management, 16(1), 1-8. https://doi.org/10.4102/sajhrm.v16i0.913

Makondo, L. (2014). Academics attraction and retention trends at a South African university. Journal of Sociology and Social Anthropology, 5(2), 169-177. https://doi.org/10.1080/09766634.2014.11885621

Meyers, M. C., van Woerkom, \& Dries, N. (2013). Talent-Innate or acquired? Theoretical considerations and their implications for talent management. Human Resources Management Review, 23(4), 305-321. https://doi.org/10.1016/j.hrmr.2013.05.003

Meyers, M. C., \& van Woerkom, M. (2014). The influence of underlying philosophies on talent management: Theory, implications for practice, and research agenda. Journal of World Business, 49(2), 192-203. https://doi.org/10.1016/j.jwb.2013.11.003

Musakuro, R. N. (2018). A framework for talent management in the higher education sector: a study at a selected university of technology, Western Cape, South Africa. Unpublished Masters' thesis. Cape Peninsula University of Technology, South Africa.

Onah, F. O., \& Anikwe, O. S. (2016). The Task of Attraction and Retention of Academic Staff in Nigeria Universities. Journal of Management and Strategy, 7(2), 9-20. https://doi.org/10.5430/jms.v7n2p9

Ponterotto, J. G. (2005). Qualitative research in counselling psychology: A primer on research paradigms and philosophy of science. Journal of Counselling Psychology, 126-136. https://doi.org/10.1037/0022-0167.52.2.126

Rudhumbu, N., \& Maphosa, C. (2015). Implementation of talent management strategies in higher education: evidence from Botswana. Journal of Human Ecology, 49(1-2), 21-32. https://doi.org/10.1080/09709274.2015.11906820

Samuel, M. O., \& Chipunza, C. (2013). Attrition and retention of senior academics at institutions of higher learning in South Africa: The strategies, complexities and realities. Journal of Social Sciences, 35(2), 97-109. https://doi.org/10.1080/09718923.2013.11893151

Selesho, J. M., \& Naile, I. (2014). Academic staff retention as a human resource factor: University perspective. The International Business \& Economics Research Journal, 13(2), 295-304. https://doi.org/10.19030/iber.v13i2.8444

Shikweni, S., Schurink, W., \& van Wyk, R. (2019). Talent management in the South African construction industry. SA Journal of Human Resource Management, 17(1), 1-12. https://doi.org/10.4102/sajhrm.v17i0.1094

Simataa, G., \& Pearse, N. J. (2018). Talent management: a case study of Namibia's Directorate of Civil Aviation (DCA) in securing talent for aviation safety. Ergonomics SA: Journal of the Ergonomics Society of South Africa, 30(1), 1-13. https://doi.org/10.4314/esa.v30i1.3 
Theron, M., Barkhuizen, N., \& Du Plessis, Y. (2014). Managing the academic talent void: Investigating factors in academic turnover and retention in South Africa. SA Journal of Industrial Psychology, 40(1), 1-14. 10.4102/sajip.v40i1.1117

Thunnissen, M., Boselie, P., \& Fruytier, B. (2013). A review of talent management: 'infancy or adolescence? The International Journal of Human Resource Management, 24(9), 1744-1761. https://doi.org/10.1080/09585192.2013.777543

van Zyl, E. S., Mathafena, R. B., \& Ras, J. (2017). The development of a talent management framework for the private sector. SA Journal of Human Resource Management, 15(1), 1-19. https://doi.org/10.4102/sajhrm.v15i0.820

Yarnall, J. (2011). Maximising the effectiveness of talent pools: a review of case study literature. Leadership \& Organization Development Journal, 32(5), 510-526. https://doi.org/10.1108/01437731111146596

\section{Copyrights}

Copyright for this article is retained by the author(s), with first publication rights granted to the journal.

This is an open-access article distributed under the terms and conditions of the Creative Commons Attribution license (http://creativecommons.org/licenses/by/4.0/). 